\title{
Assessment of the effects of gamma irradiation on the growth and yield of Digitaria exilis [Haller]
}

\author{
Animasaun, D. A.*, Morakinyo, J. A. and Mustapha, O. T \\ Department of Plant Biology, University of Ilorin, P.M.B. 1515, Ilorin, Nigeria \\ *Corresponding author: biostanleydayor@yahoo.com.au; animasaun.ad@unilorin.edu.ng
}

Original submitted in on $21^{\text {st }}$ January 2014. Published online at www.m.elewa.org on $28^{\text {th }}$ February 2014. http://dx.doi.org/10.4314/jab.v75i1.1

\begin{abstract}
Objective: Mutagenesis has been used in several crop improvement programmes but only on a very limited scale for Digitaria improvement and in order to further strengthen the existing conventional improvement methods, we report enrichment of Digitaria exilis variability by exploiting the effects of gamma radiation of different doses on yield and growth of the crop.

Methodology and Results: Digitaria exilis seeds were exposed to gamma irradiation (20Gy, 40Gy, 80Gy, and $100 \mathrm{~Gy}$ ) from ${ }^{60} \mathrm{Co}$ source and irradiated seeds were sown for evaluation. The effects of the irradiation doses were studied on germination, seedling characters, growth, and yield parameters at maturity. Days to emergence and percentage germination were enhanced at low irradiation doses with 80Gy producing optimally. Plant height, tillering and number of leaves were significantly affected by gamma irradiation and analysis of obtained data showed irradiation significantly affects percentage seed-set, number of spikes/tiller and number of spikelets/spike. Also, early maturity was achieved among irradiated plants and 100-grain weight was highest at 80Gy.

Conclusion: Plant from $80 \mathrm{~Gy}$ irradiation dose performed optimally for all the characters evaluated in this study. Hence, $80 \mathrm{~Gy}$ or slightly low dosage form of gamma irradiation using cobalt (60) could be utilised to increase variability and yield in Digitaria exilis. The new or modified traits so created could be screened for the possibility of isolating and selection of mutants that are promising for further improvement breeding programmes.
\end{abstract}

Keywords: Characters, Irradiation, Improved, Agronomical, Yield

\section{INTRODUCTION}

In the wakes of climatic change with its impending danger of food scarcity and insecurity, nearly a billion poor people of dry land environments of Africa and Asia lives depend on cereals that can be grown on drought and water stressed environments such as millet, sorghum and other dryland crops (CGIAR, 2012). The poor rural people whose main occupation is still farming awaits their salvaging crops whose genetics are well understood and require low input to develop hybrids of improved yield and stable crops for such conditions. Digitaria exilis is an important orphan crop component of food security in West Africa and is assuming a greater importance in the context of changing climate and increasing demand for highly nutritious food with low cost input. Digitaria exilis is 


\begin{tabular}{l}
$\begin{array}{l}\text { Animasaun et al. J. Appl. Biosci. 2014. Assessment of the effects of Gamma Irradiation on growth } \\
\text { and Yield of Digitaria Exilis }\end{array}$ \\
\hline
\end{tabular}

one of the promising cereals in fighting hunger in Sub- Sahara Africa (Vietmeyer et. al, 1996). Although a large number of Digitaria species are recognised as weeds, cultivated species have been identified for their use as forage and human food (Aliero and Morakinyo, 2001). D. Exilis, fondly called "Acha", "hungry rice", "fonio", "fundi" is grown in the savannah zone of the West Africa from Senegal to Cameroon and Nigeria as staple crop. It is a traditional cereal well adapted to local conditions, and has good nutritional and culinary properties (Jean-Francois, 2004). In Nigeria, Acha is majorly cultivated in Plateau, Bauchi, Kebbi, Kaduna, Niger, Kastina and Borno States and recently among the local farmers in the Federal Capital Territory area (Maji et al, 2005). Utilization of Digitaria species for food or other uses is restricted to areas of production; its relative importance has not been generally recognized over the years except in the areas of its cultivation. The small grain of Acha is used to make porridge and dishes of Acha, which showed higher preference than those of rice and millet among the growers (Jean-Francois, 2004). The flour is used along with baobab milk to produce mixture of high nutritional value (Obizola and Anyinka, 1994). D. exilis grain is used for brewing beer and the straw provides useful fodder, stuffing of mattresses or livestock bedding and raw materials for local soap and paper industry (Phillips, 1977). Awolola (1984) reported an increase in the consumption of acha in Nigeria and that the percentage in food demand increases with increase in yield over the years. Acha is one of the worlds' fastest growing cereal and its potential to provide food early in season when other crops are yet to mature for harvesting could be effective in fighting hunger in a continent that is ravaged by poverty, drought and flood (Kuta et al., 2003; Uwakungwu et al., 2003; Dachi and Gana, 2008). D. exilis have great genetic developmental potentials and its long storage life

\section{MATERIALS AND METHODS}

Seeds of $D$. exilis (Ex-Sum-I) with accession number vde 004 were collected from the National Cereal Research Institute, Badeggi, Niger-State of Nigeria. Seed colour, shape and seed coat texture were and keeping qualities are particularly of importance in replacing the super cereals in industrial and food production of tomorrow. It has ambient ability to survive continuous and intermittent drought conditions that occur because of rainfall fluctuation. Acha production in Nigeria is faced with a number of problems, one of which is low yield (Dachi and Barko, 2003; Maji et al., 2003; Ukwungwu et al., 2003). Due to the low grain yield and the small grain size that shatters and matures unevenly, the crop has not been fully exploited and has generally remained unimproved. The very small grain size of Acha largely constitutes a problem in harvesting and makes mechanical harvesting almost impracticable due to its logging, which is a wild character (Morakinyo and Adelakun, 1997). Currently, the genetic improvement of Acha centres on germplasm collection and morpho-agronomic characterization with the objective of broadening the crop gene pool. However, morphological characterization alone might not provide the much needed diversity for breeding programme. Also, the traditional hybridization for new cultivar appears unfeasible due to the miniature size of the floral organs and inadequate floral biology. Very little information is available on $D$. exilis improvement by mutagenesis and therefore, this work aimed at assessing the effects of application of gamma irradiation from ${ }^{60} \mathrm{Co}$ source on the growth characteristics of the crop. Mutagenesis has been used to introduce novel genetic variability in a number of crops. More recently, it has become a powerful tool in gene discovery (Pathirana et al., 2002; Amanda et al., 2008). Improvement is hoped to be achieved in vegetative characteristics, yield components and maturity. To this end, the present study will evaluate gamma radiation effects on Digitaria exilis with a view determine the optimum dose that will create useful variability in the vegetative structure and improve the yield components of the crop.

observed and recorded before and after the treatments were applied. $150 \mathrm{~g}$ of dry seeds were exposed to Gamma-radiation of ${ }^{60} \mathrm{Co}$ at Sheda Science and Technology Complex (NTC SHESTCO), Abuja, Nigeria. 


\begin{tabular}{l}
$\begin{array}{l}\text { Animasaun et al. J. Appl. Biosci. 2014. Assessment of the effects of Gamma Irradiation on growth } \\
\text { and Yield of Digitaria Exilis }\end{array}$ \\
\hline
\end{tabular}

Four doses of irradiation were assayed in increasing concentrations of $20,40,80$, and $100 \mathrm{~Gy}$, ranging from $0.020-0.10 \mathrm{kGy}$ ( $1 \mathrm{~Gy}$ is equivalent to 100 rads of radiation). Alanine Dosimeter was used to verify the dosage conformation. After the dosage confirmation, the treated seeds for each radiation dosage were kept in a paper envelop, well sealed till sowing time. The control seed were soaked in distilled water for $3 \mathrm{hrs}$ before planting. The seeds were sown (broadcasted) on nursery beds rich in loamy soil $(0.5 \mathrm{~m} \times 0.5 \mathrm{~m})$ for each of the treatments and control. The experiment was designed in a Complete Randomized Design (CRD), nursery management such as watering and shading was provided and weeding was done as required. Seedlings were transplanted three weeks after sowing, three (3) plants were transplanted into planting bag filled with loamy soil and labelled corresponding to the treatment of the seedlings in five

\section{RESULTS}

Seed colour, shape and texture were the same before and after treatment. This suggests that the treatments have no observable effect on the seed morphology of D. exilis. Germination was fastest in 80 Gy seed with mean germination of 5.1 days, and $92 \%$ percentage germination. The average germination day for the untreated seeds was 6.2 days, but with the highest percentage germination of $93 \%$. Nonetheless, other replicates arranged in random order inside the screen house. Parameters on which treatments were evaluated include; number of days to emergence, percentage germination, number of leaves/tiller, plant height, number of nodes per plant, inters node length, leaf width, leaf length, number of tiller/plant, leaf sheath length, number of days to maturity, peduncle length, spike length, number of spike/plant, number of days to $50 \%$ flowering, number of spikelets/spike, percentage seed set and 100-grain weight. Quantitative data obtained on the vegetative growth and yield of the treated $D$. exilis were analyzed using SPSS 16.0 Microsoft Software for Window. The data was subjected to analysis of variance (ANOVA) to determine significant of variations due to effect of irradiation doses on the plants and the means were separated using Duncan Multiple Range Test (DMRT).

different doses of radiation produced relatively good germination effect on the seeds. Figures 1 and 2 show the mean number of days to germination, percentage germination and the percentage survival of the seedling after transplant. Survival rate was highest for the control with $96.41 \%$ and closely followed by the $80 \mathrm{~Gy}$ seedlings (95.39\%), while $20 \mathrm{~Gy}, 40 \mathrm{~Gy}$ and $100 \mathrm{~Gy}$ recorded $92.1 \%, 93.35$ and $86.81 \%$ respectively.

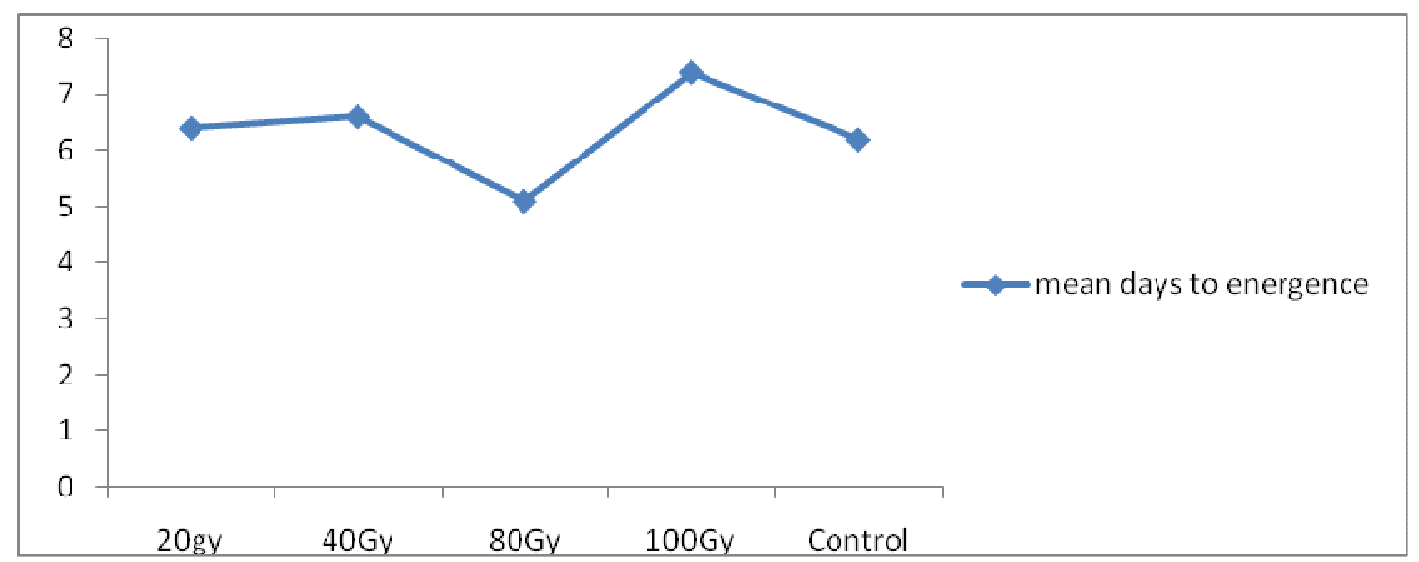

Fig 1a: Chart showing mean number of days to germination of Digitaria exilis in response to gamma radiation treatments 


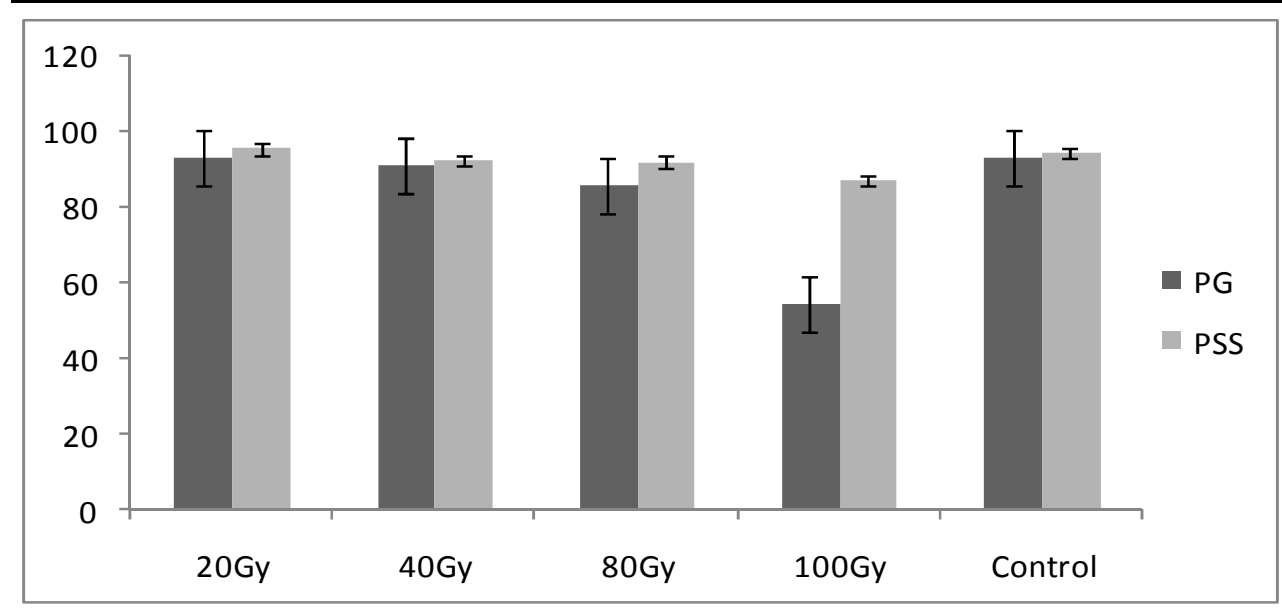

Fig 1b: Chart showing mean percentage germination (PG) and Percentage seedling survival (PSS) of Digitaria exilis in response to gamma radiation treatments

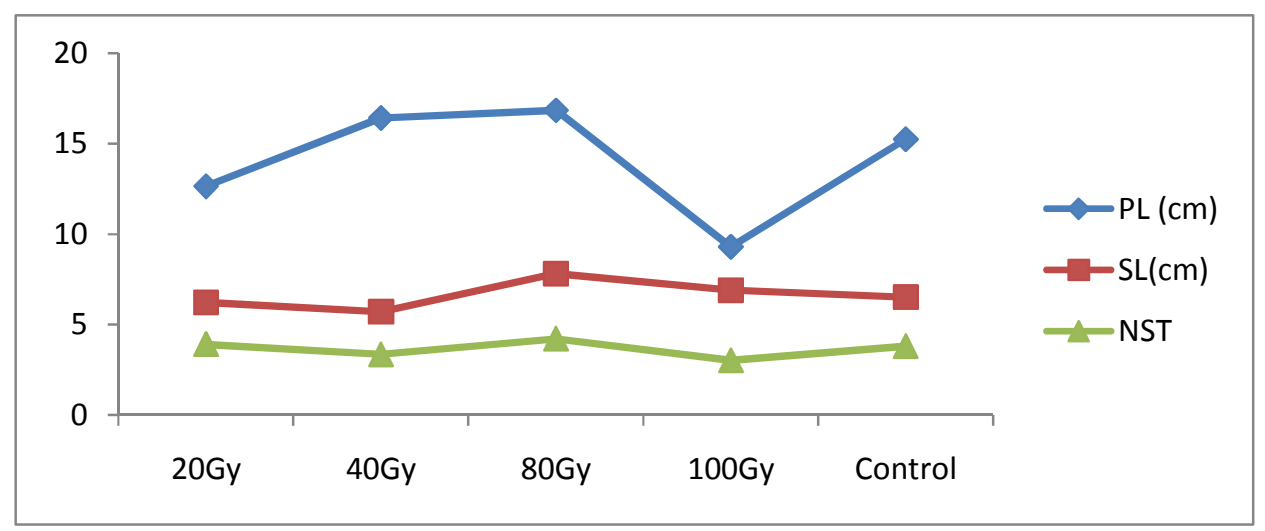

Fig 2: Showing mean Peduncle length (PL), Spike length (SL) and Number of spike/tiller of Digitaria exilis treated with different doses of gamma radiation

On emergence, seedlings of 20 Gy radiation and control are similar with green leaves, green leaf sheaths and green stem bases. Other irradiated seedlings, had reddish-green leaves, sheaths and reddish stem bases. The quantitative characters studied 3weeks after sowing; number of leaves was highest in 80 Gy group with a mean value of 4.2 , followed by the 40 Gy which had mean value of 3.6 and control 3.4 while 100 Gy had the lowest value of 2.8 . Leave length and plant height at 3weeks after sowing trends were similar to the number of leaves for all the treatments, while the highest mean plant height was obtained in 80 Gy seedlings (Table 1).

Table 1: Quantitative characteristics of $D$. exilis 3 weeks after sowing

\begin{tabular}{lccc}
\hline Treatments & No of leaves & Leaf length $(\mathbf{c m})$ & Plant height $(\mathbf{c m})$ \\
\hline $20 \mathrm{~Gy}$ & $3.2 \pm 1.30$ & $2.2 \pm 0.61$ & $3.26 \pm 0.48$ \\
$40 \mathrm{~Gy}$ & $3.6 \pm 1.14$ & $1.6 \pm 0.91$ & $3.88 \pm 0.38$ \\
$80 \mathrm{~Gy}$ & $4.2 \pm 1.30$ & $3.4 \pm 1.06$ & $4.06 \pm 0.21$ \\
$100 \mathrm{~Gy}$ & $2.8 \pm 0.84$ & $1.6 \pm 0.30$ & $3.24 \pm 0.55$ \\
\hline Control & $3.4 \pm 1.14$ & $2.8 \pm 0.91$ & $3.82 \pm 0.63$
\end{tabular}


At maturity, $D$. exilis showed different responses to the mutagenic treatments of different level of dosages. Plant height was highest in 80 Gy plant $(99.8 \mathrm{~cm})$ among all the irradiated plants; the mean plant height values were high with no value less than $90.0 \mathrm{~cm}$. In addition, the response of plant leaf length to treatment varied for all the treatment applied. The leaf length for $80 \mathrm{~Gy}$ was the highest $(19.84 \mathrm{~cm})$. The $20 \mathrm{~Gy}$ and 40 Gy plants responses to treatment in term of leaf length were very close and not significantly different (20 Gy$17.56 \mathrm{~cm}$ and $40 \mathrm{~Gy}-17.6 \mathrm{~cm}$ ), but significantly difference from leaf length of the control plants (16.28 $\mathrm{cm}$ ) and $100 \mathrm{~Gy}$ plant with least mean leaf length $(15.62 \mathrm{~cm})$. The highest number of tillers per plant was observed in 40 Gy plants (11.6) while the control plants produced an average of 8.4 tillers per plant. Other quantitative observations on the vegetative characters of the treatments were summarized in the Table 2 . The levels of significant differences in all the examined characters were indicated. The DMRT analysis showed that treated plants were significantly different in the number of nodes/plant, inter-nodal length and number of days to maturity. Treatment effects were highest in the irradiated plants of $80 \mathrm{~Gy}$. The number of spikelets per spike varied with $80 \mathrm{~Gy}$ plants having the highest spikelet per spike, followed by 20 Gy plants and control plants with 95.8, 92.6 and 90.2 mean values respectively. Also, plants responses to gamma radiation treatment differ with regards to fruiting characteristics such as peduncle length, spike length and number of spike per tiller (Fig. 2). Weight of 100 grains for $80 \mathrm{~Gy}$ plants had the highest value and was closely trailed by 40 Gy plants and control seeds (Fig. 3). 
Table 2: Quantitative characters of Digitaria exilis in response to treatments by doses of gamma radiation

\begin{tabular}{|c|c|c|c|c|c|c|c|c|c|}
\hline Treatments & $\begin{array}{l}\text { No of } \\
\text { tiller/plant }\end{array}$ & $\begin{array}{l}\text { Leaf } \\
\text { length }(\mathrm{cm})\end{array}$ & $\begin{array}{l}\text { No of } \\
\text { nodes/tiller }\end{array}$ & $\begin{array}{l}\text { Inter nodal } \\
\text { length (cm) }\end{array}$ & $\begin{array}{l}\text { Plant height } \\
(\mathrm{cm})\end{array}$ & $\begin{array}{l}\text { Leaf sheath } \\
\text { length(cm) }\end{array}$ & $\begin{array}{l}\text { Leaf width } \\
\text { (cm) }\end{array}$ & $\begin{array}{l}\text { No of days to } \\
\text { maturity }\end{array}$ & $\begin{array}{l}\text { No of } \\
\text { spikelet/spike }\end{array}$ \\
\hline $20 \mathrm{~Gy}$ & $10.21 \pm 1.03 b$ & $17.56 \pm 1.09 b$ & $7.80 \pm 0.580 a$ & $6.68 \pm 0.48 b$ & $93.34 \pm 3.21 a$ & $5.32 \pm 0.32 \mathrm{abc}$ & $0.76 \pm 0.04 a$ & $79.20 \pm 2.47 a$ & $92.60 \pm 2.78 a$ \\
\hline 40Gy & $11.60 \pm 1.15 a$ & $17.60 \pm 1.20 \mathrm{~b}$ & $7.20 \pm 1.019 b$ & $6.66 \pm 0.57 b$ & $98.52 \pm 3.31 a$ & $5.82 \pm 0.54 a b c$ & $0.66 \pm 0.09 \mathrm{ab}$ & $82.40 \pm 2.66 \mathrm{~b}$ & $90.31 \pm 2.89 a$ \\
\hline $80 G y$ & $11.30 \pm 1.09 a$ & $19.84 \pm 1.73 a$ & $7.60 \pm 1.872 a$ & $8.05 \pm 0.54 a$ & $99.82 \pm 2.96 a$ & $6.82 \pm 0.48 a$ & $0.23 \pm 0.07 c$ & $87.60 \pm 4.63 b$ & $95.80 \pm 2.96 a$ \\
\hline 100Gy & $8.51 \pm 1.03 c$ & $15.62 \pm 1.30 c$ & $5.80 \pm 0.347 c$ & $6.42 \pm 0.76 b$ & $90.46 \pm 2.54 b$ & $5.90 \pm 0.48 b$ & $0.70 \pm 0.08 b$ & $89.80 \pm 3.44 \mathrm{abc}$ & $87.12 \pm 2.76 b$ \\
\hline (control) & $8.42 \pm 0.99 c$ & $16.28 \pm 1.26 a b$ & $7.20 \pm 0.53 b$ & $6.10 \pm 0.44 b$ & $95.60 \pm 2.52 a$ & $0.424 \pm 0.21 \mathrm{c}$ & $0.76 \pm 0.23 a$ & $92.60 \pm 2.12 \mathrm{c}$ & $90.25 \pm 2.61 \mathrm{a}$ \\
\hline
\end{tabular}

Probability level $P<0.05$

Values with same alphabet are not significantly difference along the column while values followed by different alphabets are significantly different. 


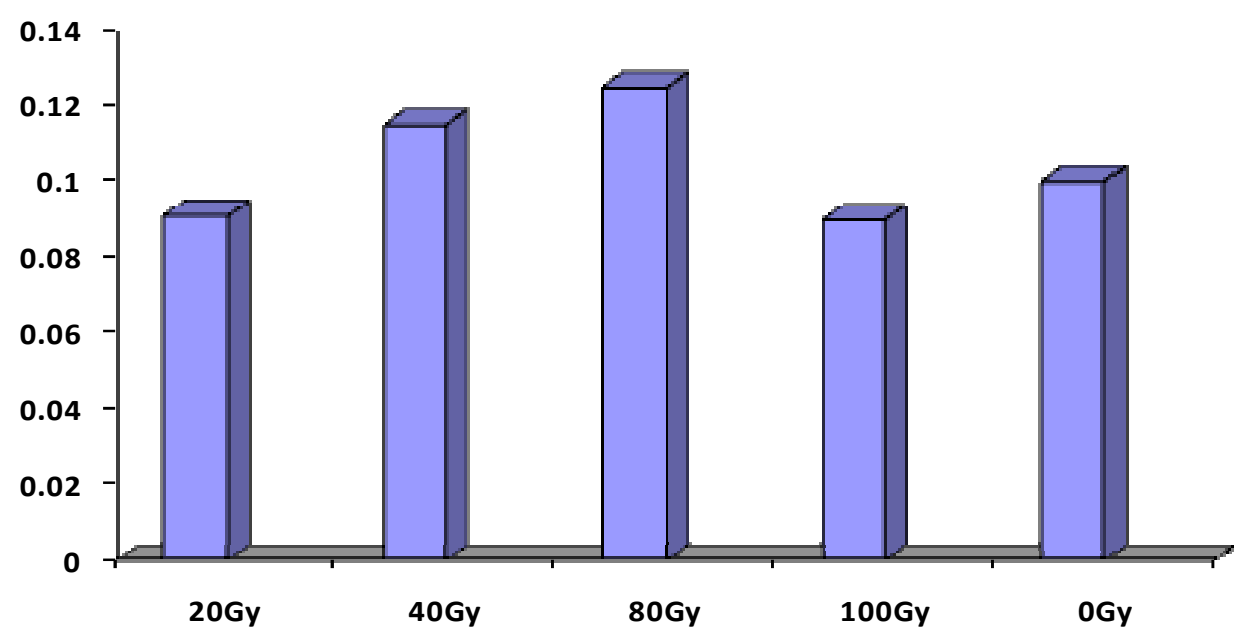

Fig 3: 100-seed weight (g) of $\mathrm{M}_{1}$ progeny of Digitaria exilis exposed to different gamma radiation doses

\section{DISCUSSION}

Both quantitative and qualitative characters evaluated showed distinct differences in most of the characteristics, though there were few characteristics with no significant differences in responses to the applied treatments. The ability of the irradiated seeds to germinate between 4-8 days in respect to the control showed that the irradiation induced increase enzymatic activities, which could be responsible for the early germination. This is in agreement with earlier report by Kaplan, (1963) partially in agreement with Mensah et. al, (2007) who reported that germination decreases with increase in dose of chemical mutagens while working on sesame seeds. In the present study, 80 Gy seeds responded vigorously to germination just as 20 $\mathrm{Gy}$ and $40 \mathrm{~Gy}$ treated seeds germinated earlier than the control, although $100 \mathrm{~Gy}$ had negative effect on germination. It therefore suggested that at optimal dose, irradiation can be used to induce germination in Acha. However, percentage germination and seedling survival reduced with increase in irradiation dosage. Many workers have reported adverse effects of physical and chemical mutagens on percentage germination and seedling survival of crops (Mensah et. al, 2007; Khan and Goyal, 2009; Chowdhury and Tah, 2011; Shagufta et. al, 2013). The reduced percentage germination and seedling survival at high dosage of irradiation possibly indicate the greater sensitivity of the crop due to occurrence of more genic chromosomal and physiological disturbances at these concentrations. Plant height, tillering, leaf formation, and other vegetative traits studied responded to $80 \mathrm{~Gy}$ irradiation.
This implies that 80 Gy or slightly less doses would be appropriate in producing optimal effects in respect to the vegetative characters, although higher dosage exposure of the crop to gamma irradiation resulted in negative response. This correlates with the findings of Mensah et. al. (2005) and Warghat et. al., (2011) who reported that appropriate application of dosage or concentration of mutagens improves vegetative yields of cowpea (Vigna uguiculata) and Musk okra (Abelmoschus moschatus). The growth effects observed could be attributed to mitotic activities which are sustained from seedling till maturity, resulting in the proliferation of axilllary bud in response to irradiation as studied by Prat (1967). The marked differences observed in the studied characters even at the level of different dosages could have arisen from mutagenic effects of the gamma irradiations on the DNA and genetic structure of the plants. This position is corroborated by the work of Reddy and Smith (1994), who opined that chemical mutagen (EMS), induced notable vegetative characters in treated Sorghum bicolour. Considering seed characters, variations were observed in the number of spikelets produced per spike and percentage seed set was highest among 80Gy plants. The average weight of 100 -grains for $80 \mathrm{~Gy}$ was also the highest. This result concurred with the reports of Shamsi and Sofajay, (1980) and Shamsulzlaman et al., (2005) who had earlier reported increased in yield of crops treated with mutagens. The effects of gamma irradiation of 80 Gy on D. exilis as observed in this study could have arisen from changes in genetic 


\begin{tabular}{l}
$\begin{array}{l}\text { Animasaun et al. J. Appl. Biosci. 2014. Assessment of the effects of Gamma Irradiation on growth } \\
\text { and Yield of Digitaria Exilis }\end{array}$ \\
\hline
\end{tabular}

material which promotes growth and yield of the plants. While irradiation doses of $20 \mathrm{~Gy}$, and $40 \mathrm{~Gy}$ were not possibly enough to effect significant developmental and growth effects on the plants of the treated seeds. 100 Gy irradiation dose among all the levels of irradiations

\section{CONCLUSION}

This study has established that ionizing radiation mutagenesis could be routinely used to generate genetic variability for breeding improved crop and for the purpose of genetic studies in $D$. exilis. In order to increase the likelihood of inducing distinct type of genetic variation in the crop, gamma rays of $80 \mathrm{~Gy}$ radiation, which consistently produced the optimal

\section{REFRENCES}

Aliero AA. and Morakinyo JA, 2001. Characterization of Digitaria exilis (Kipp) Stapf and D. iburua Stapf. accessions. Nigeria Journal of Genetics 16: 10-21.

Amanda SB, Zucchi IM, Tulmann-Neto A, Quecini V, 2008. Mutagenesis in Petunia x hybrida Vilm. and isolation of a novel morphological mutant. Brazilian Journal of plant Physiology 20 (2): 95-103.

Awolola ND, 1984. The effects of different educational types on Agricultural Development in Nigeria: The case study of five villages in Zaria area of Kaduna State. Ph.D. Thesis submitted to the Department of Agricultural Economics and Rural Sociology, ABU, Zaria (unpublished) $p$ 221.

CGIAR, 2012. Research programme on Dryland Cereals: Dryland Cereals Publication $29 \mathrm{pp}$.

Chowdhury R. and Tah J, 2011. Assessment of chemical mutagenic effects in mutation breeding programme for $M_{1}$ generation of Carnation (Dianthus caryophyllus). Research in Plant Biology, 1(4): 23-32

Dachi SN. and Barko SN, 2003. Nigerian Cereal Research Institute Acha Programme. NCRI Annual Report. Badeggi, : 85-90.

Dachi SN. and Gana AS, 2008. Adaptability and yield evaluation of some Acha (Digitaria exilis and Digitaria iburua kippis Stapf) accessions at Kusogi - Bida, Niger State, Nigeria. African Journal of General Agriculture 4(2): 73 - 77

Jean-Francois C, 2004. Fonio: a small grain with potential. ELISA Magazine. 20(1): 1-4

Kaplan HS, 1963. Biochemical Basis of Reproductive Death in Irradiated Cells. American Journal of tested produced the least desirable effects in almost all the evaluated characters of the Acha plants studied. Therefore, the dosage of $100 \mathrm{~Gy}$ had likely overshot the required gamma irradiation dosage for optimal growth and yield of $D$. exilis.

effects on the crop should be adopted and for effective mutation breeding, character to be bred for should be singly screened and appropriate dosage for the treatment of such crop should be applied. It is also worthy of mentioning that in using irradiation for $D$. exilis to enhance variability, the probable optimal dose range lies between $65-85 \mathrm{~Gy}$.

Radiation Therapy and Nuclear Medicine, 90: 902-916

Khan S. and Goyal S, 2009. Improvement of Mungbean Varieties through induced mutation. African Journal of Plant Science,3: $174-180$.

Kuta DD, Kwon-Ndung E., Dachi S., Ukwungwu M, Imolehin ED, 2003. Potential role of Biotechnology tools for genetic improvement of 'lost crops of Africa': the case of fonio (Digitaria exilis and Digitaria iburua), African Journal of Biotechnology, 2(12): $580-585$.

Maji AT, Dachi SN, Yisa J, 2003. Evaluation of Morphological variations within and between 10 Acha collection in NCRI accessions. NCRI Annual Report, 90-94.

Maji AT, Dachi SN, Yisa J, 2005. Improvement of Acha accession at NCRI, Badeggi, NCRI Annual Report. 83-93

Mensah, J. K., Akomeah, P. A. and Ekpekurede, E. O. (2005). Gamma irradiation induced variation of yield parameters in cowpea (Vigna uguiculata (L.) Walp). Global Journal of Pure and Applied Science, 11(3):327-330.

Mensah JK, Obadoni BO, Akomeah PA, Ikhajiagbe B, Ajibulu J, 2007. The effects of Sodium azide and Colchicine treatments on morphological and yield traits of sesame seed (Sesame indicum L.). African Journal of Biotechnology, 6(5):534-538.

Morakinyo JA. and Adelakun A, 1997. Effects of gamma radiation on meiosis and pollen viability in ,Digitaria exilis Nigeria Journal of Genetics. xi: 29-36.

Obizola IC. and Anyinka JU, 1994. Nutrient values of baobab milk (gubdi) and mixtures of baobab 
(Adansonia digitata) and hungry rice, acha (Digitaria exilis) flours. Plant foods Human nutr. 46 (2): 157-165.

Pathirana R, Wijithawarna WA, Jagoda K, Ranawaka $A L, 2002$. Selection of rice for iron toxicity tolerance through irradiated caryopsis. Plant Cell Tissue and Organ Culture, 70: 83 - 90

Phillips TA, 1977. An Agricultural notebook-with special reference to Nigeria. (New edition) Longman Groups Ltd. London. $312 \mathrm{pp}$

Prat H, 1960. Vers une Classification naturelle des Graminées. Bull. Soc. Bot. 107: 32-79

Reddy CS and Smith JO, 1984. Mutagenic Effectiveness and Efficiency of EMS in Sorghum bicolor. Indian J. of Genetics, 44 (1): 48-54

Shagufta B, Aijaz AW, Irshad AN, 2013. Mutagenic sensitivity of Gamma rays, EMS and sodium azide in Trigonella foenum-graecum $\mathrm{L}$. Science Res. Rep. 3(1): 20-26

Shamsi SRA, and Sofjay SA, 1980. Effect of low doses of gamma radiation on the growth and yield of two cultivars of broadbean. Environmental and Experimental Botany, 20: 87 - 94

Shamusuzzaman KM, Islam MM, Muwara B, 2005. Development of an early maturing chickpea variety. Breeding Newsletter and Reviews, 1: 23

Ukwunguwu MN, Bakare SO, Kuta DD, Dachi SN. 2003. Evaluation of accessions of Acha in Badaggi. NCRI Annual Report: 148-157.

Vietameyer ND, Borlaugh NE, Axtell J, Burton GW, Harlan JR, Rachie KO, 1996. Fonio, In: Lost crops of Africa (1), Grain BOSTID publications. National Academy Press, New York.

Warghat AR, Rampure NH, Wagh P, 2011. Effect of Sodium azide and Gamma rays treatments on percentage germination, survival, morphological variation and chlorophyll mutation in Musk okra, (Abelmoschus moschatus L.), International Journal of Pharmacy and Pharmaceutical Sciences, 3(5):483-486. 